
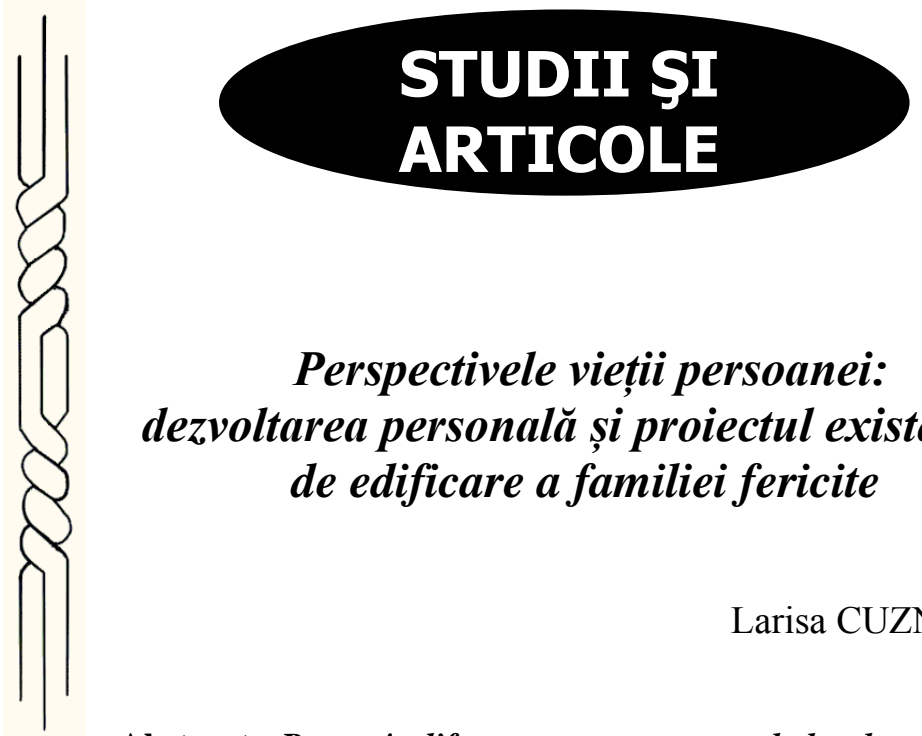

\title{
Perspectivele vieții persoanei: dezvoltarea personală și proiectul existențial de edificare a familiei fericite
}

Abstract: Person's life prospects: personal development and the existential project of building a happy family. The article contains a theoretical study with praxiological implications, which elucidates a brief foray into the landmarks and possibilities of positive psychology to guide young people to personal development in the context of knowing life prospects and developing the Existential Project to build a happy family. The author analyzes the flexible and rigid mentality of the person, which is correlated with the perspectives of life, mentioning the strong and vulnerable aspects of the perspectives: accentuated-positive on the past; moderate-positive on the future and moderate - hedonistic and eudaimonic on the present. In this context, a mini-research is presented on determining the type of perspectives that prevail in young people and adults, including how they can influence building and maintaining a happy family. Next, two types of people are described, some who make maximalist choices and others who focus on satisfactory choices. It also explains the reason for the functionality of satisfactory elections. The aspects analyzed and interpreted in the study in question contributed to the determination of the conditions for the successful

* Prof. univ. dr. habil., Universitatea Pedagogică de Stat „Ion Creangă” din Chişinău, Republica Moldova. 
elaboration and application of the Existential Project for building a happy family; of strategies/ steps to maintain it and optimize the personal efficiency of marital partners.

Keywords: family, existential project, life prospects, flexible mentality, rigid mentality, personal development.

Fiecare om vrea să fie fericit, însă nu există un anumit lucru care îl poate face fericit. Această tendinţă a omului reprezintă obiectul de studiu al Psihologiei pozitive, întemeiată şi promovată de doi savanţi remarcabili, de M. Seligman şi M. Csikzentmihalyi. Psihologia pozitivă ca un domeniu relativ nou al ştiinţelor despre om şi educaţie, are un scop nobil de a reuni cercetările psihologilor umanişti, a sociologilor, antropologilor, biologilor, geneticienilor, psihiatrilor, filosofilor şi a pedagogilor, care ţin de formarea şi consolidarea cunoştinţelor şi competenţelor generale ale oamenilor, pentru a determina căile ce duc la succes, bunăstare, prosperitate şi înflorire, atât din punct de vedere individual, cât şi cultural ${ }^{1}$.

După cum am menţionat anterior în cercetările şi lucrările noastre $^{2}$, tendinţa omului spre dezvoltarea personală şi autoactualizare materializată într-un plan şi acţiuni concrete de autoperfecţionare în multiple domenii: intelectual, moral, psihofizic, estetic, tehnologic şi desigur că familial şi profesional, va determina alegerile raţionale, autonome, dar şi de comun acord cu potenţialul partener conjugal şi/ sau profesional (în anumite situaţii) privind proiectarea perspectivelor vieţii, a scopurilor, strategiilor de realizare a acestora şi a obiectivelor vieţii personale, inclusiv a vieţii familiale.

Dezvoltarea personală pe parcursul vieţii poate părea unor persoane o povară, însă, dacă acţiunile de autoperfecţionare a individului se realizează într-o cheie pozitivă (în baza principiilor psihologiei pozitive), acestea, deja au devenit o convingere, deprindere, obişnuinţă - apoi desfăşurarea procesului vizat se

${ }^{1}$ Charlotte STYle, Psihologia pozitivă. Ce ne menţine fericiţi, optimişti şi motivaţi, Bucureşti, Edit. All, 2015, p. 6.

${ }^{2}$ Larisa Cuznețov, Tratat de educatie pentru familie. Pedagogia familiei, Chişinău, CEP USM, 2008, p. 257-260; IDEM, Familia ca Proiect Existenţial. Management familial, Chişinău, Primex Com - SRl, 2019, p. 33-35. 
transformă într-un demers conştient şi plăcut de descoperire şi valorificare a propriului potenţial, iar mintea devine flexibilă, fiind axată pe setea de cunoaştere, de creativitate şi deschidere a sinelui pentru ceva nou, original şi centrat pe schimbare. Evident că ne interesează condiţiile edificării familiei fericite în contextul dezvoltării personale şi a abordării perspectivelor vieţii, de aceea vom începe acest studiu cu un postulat cunoscut din psihologia pozitivă: abilitatea persoanei de a se adapta şi a învăţa este o componentă-cheie a fericirii şi bunăstării psihologice ${ }^{3}$. De obicei, oamenii cu o mentalitate flexibilă iubesc să înveţe, acceptă provocările şi experienţele noi, înţeleg că ratările şi eşecurile sunt nişte experienţe neplăcute, dar, totodată, sunt şi nişte oportunităţi de resemnificare, reevaluare a situaţiei, de perfecţionare şi dezvoltare continuă ${ }^{4}$. Un şir de cercetători din domeniul psihologiei pozitive, printre care şi C. Dweck, susţin că atunci când persoana are mintea deschisă şi conştientizează potenţialul său, studiază, învăţă şi înţelege lumea în care trăieşte, aceasta îi asigură sporirea competenţei şi eficienţei, ghidează dezvoltarea şi actualizarea permanentă de sine, în timp ce ideile fixe, mintea pasivă şi rigidă reduc şi limitează nu numai propriul potenţial, dar şi şansele la dezvoltare, fericire, descoperiri interesante şi valoroase. În sensul dat, conchidem că este oportun să precizăm ce înseamnă o mentalitate flexibilă şi una rigidă $\breve{a}^{5}$

Aşadar, atunci când persoana este deschisă la idei noi, învaţă în permanenţă, se bucură de provocări şi le depăşeşte, crede în dezvoltarea abilităţilor, este convinsă că viaţa, realităţile acesteia, ea însăşi şi ceilalţi oameni pot să se dezvolte, sunt în stare să depună efort, au succes în realizarea scopurilor şi obiectivelor existenţiale, în construirea relaţiilor interpersonale; gândeşte şi elaborează proiecte de viaţă şi le valorifică cu succes, aceasta posedă o mentalitate flexibilă. Dacă persoana consideră că talentul şi inteligenţa sunt numai înnăscute şi nu pot fi exersate şi dezvoltate, este prea

${ }^{3}$ Charlotte STYLE, op. cit., p. 9.

${ }^{4}$ Ibidem, p. 30.

${ }^{5}$ Carol M. DwEC, The new psychology of succes, New York, Ballantne Books, 2006, p. 30-33. 
auto/critică, provocările şi dificultăţile o sperie, are realizări limitate, consideră că relaţiile care presupun efort nu sunt suficient de bune, este convinsă că lucrurile trebuie să vină de la sine, nu se orientează spre nou, spre învăţare, descoperire, creaţie, evită ieşirea din zona de confort propriu etc. - posedă o mentalitate rigidă.

Observaţiile şi experienţa de viaţă, studiile ştiinţifice din domeniul vizat ne sugerează că cel mai important lucru în dezvoltarea personală constă în faptul de a fi conştient, a exersa mintea pentru a avea o mentalitate flexibilă, a avea dorinţa de schimbare; a fi gata pentru eforturi substanţiale moral-volitive şi intelectuale. Evident că dacă omul este liber şi orientat în antrenarea gândirii, a direcţionării ei spre pozitivism pentru a deveni eficient în elaborarea şi explorarea proiectelor noi, el are şanse mari pentru prosperare, dezvoltarea echilibrată a perspectivelor vieţii, optimizarea agerimii, profunzimii, supleţei gândirii şi desigur că pentru a cultiva mentalitatea flexibilă şi a edifica bunăstarea şi fericirea, a păstra armonia interioară şi cea familială.

În ceea ce privește abordarea perspectivelor vieții, specialiştii din domeniul psihologiei pozitive ${ }^{6}$ deosebesc perspective pozitive şi negative. Acestea, influenţând calitatea vieţii persoanei, sunt într-o legătură strânsă cu tipul mentalităţii omului şi pot fi ajustate la trecut, prezent şi viitor ${ }^{7}$.

Dacă individul este o persoană cu o perspectivă pozitivă asupra trecutului, atunci el are amintiri plăcute şi o identitate pozitivă, modelată de o copilărie şi adolescenţă, de experienţe sănătoase, valoroase, interesante şi fericite din trecutul său.

Dacă individul este o persoană cu o perspectivă negativă asupra trecutului, el va percepe trecutul ca pe un cumul de experienţe neplăcute, negative şi nefericite, iar identitatea lui va fi modelată de amintiri regretabile şi de nenumărate complexe. $\mathrm{Cu}$ toate că există unele opinii vizavi de faptul că oamenii axaţi pe o perspectivă negativă asupra trecutului sunt mai sensibili, mai delicaţi şi mai vulnerabili, există şi opinii opuse, conform cărora,

\footnotetext{
${ }^{6}$ Ilona Boniwell, Positive Psychology in a Nutshell, Londra, PWBC, 2006, p. 6061; Charlotte STYLE, op. cit., p. 39-41.

${ }^{7}$ Charlotte STYLE, op. cit., p. 40-42.
} 
Perspectivele vieții persoanei: dezvoltarea personală și proiectul existențial de edificare a familiei fericite

oamenii, care au trecut prin perspective şi experienţe negative sunt mai rezilienţi şi mai volitivi, dar, uneori sunt duri, manifestă impertinenţă existenţială . Noi, însă, considerăm că dorinţa puternică şi tendinţa omului de a schimba situaţia, condiţiile, orientarea sa de principiu, de a planifica şi monitoriza rezonabil acţiunile sale, autoactualizându-se, depunând voinţă şi efort sistematic în direcţia dată - fac minuni, fiind posibilă antrenarea capacităţii de anihilare şi/sau depăşire a influenţelor anterioare nefaste şi a dificultăţilor prezentului şi trecutului.

Perspectiva asupra prezentului pentru mulţi oameni este mult mai importantă şi mai vizibilă. În acest aspect, psihologia pozitivă ne orientează asupra delimitării persoanelor prezenthedoniste şi a persoanelor prezent-fataliste ${ }^{9}$.

Persoanele prezent-hedoniste sunt mulţumite şi bucuroase de ceea ce fac şi cum fac, caută plăceri, îşi trăiesc clipa fericit, o savurează, sunt în totalitate prezente şi se simt bine.

Persoanele prezent-fataliste se simt neajutorate, percep acut faptul că nu deţin controlul asupra vieţii sale, se simt neputincioase în faţa valurilor şi evenimentelor vieţii, care, accidental, le duc unde vor ele, deseori modelând un şir de situaţii dificile sau chiar, situații-limită.

În această ordine de idei şi plecând de la ipoteza, conform căreia capacitatea de a explora mai activ perspectivele vieţii de prezent şi de viitor sunt o prerogativă doar a tinerilor, am realizat o mică cercetare pe un eşantion stratificat de 2000 de subiecţi, care era compus din tineri (20-35 de ani) şi adulţi (35-50 de ani). Rezultatele obţinute au fost următoarele:

- după cum şi ne-am aşteptat, tinerii au demonstrat că în marea lor majoritate sunt axaţi pe perspectivele prezent - hedoniste (59 \% de subiecţi). Ei au fost în stare să le explice, să le structureze după importanţa lor $(34 \%$ subiecţi au plasat sănătatea, familia, profesia interesantă pe primul loc; $25 \%$ - au optat pentru carieră mai întâi, apoi pentru celelalte valori);

${ }^{8}$ Ibidem, p. 43.

${ }^{9}$ Larisa CuZnețov, Familia ca Proiect Existențial. Management familial..., p. 3235. 
- 29\% de tineri au optat pentru perspective de viitor, care, la fel, aveau un caracter hedonist;

- $12 \%$ de tineri s-au dovedit a fi orientaţi spre perspective de tip prezent-fatalist, deci aveau evident nevoie de o consiliere centrată pe dezvoltarea conştiinţei şi stimei de sine, formarea încrederii în propriile forţe şi un ajutor orientat spre susţinerea dezvoltării eficienţei personale, luarea deciziilor, resemnificarea după anumite eşecuri, fortificarea optimismului etc.

Cât priveşte adulţii, opţiunile acestora au fost, practic impărţite astfel: $31 \%$ de subiecţi au optat pentru perspective prezent hedoniste; $26 \%$ - pentru perspective de viitor, dar cu caracter destul de moderat; $24 \%$ au optat pentru o perspectivă accentuatpozitivă asupra trecutului, iar $19 \%$ de adulţi au ales perspectiva prezent-fatalistă.

În esenţă, ipoteza noastră s-a confirmat, dar considerăm necesar să realizăm unele explicaţii şi precizări. Bineînţeles că în viaţa cotidiană a persoanei, orientarea exclusivă şi excesivă spre oricare din aceste perspective este dăunătoare şi poate aduce la aceea că hedonistul nu va avea nici o limită în trăirea plăcerilor, iar fatalistul - nu vă găsi nici o motivaţie de a se implica mai activ şi responsabil în propria existenţă pentru a acţiona mai activ şi optimist, autonom şi sigur.

Întrucât este important să conştientizăm influenţa tuturor perspectivelor, în continuare, vom analiza perspectiva asupra viitorului. O persoană orientată spre viitor are anumite scopuri, obiective şi o direcţie clară în viaţă. Observaţiile şi investigaţiile noastre, rezultatele multor cercetări sociologice şi psihologice ${ }^{10}$ demonstrează că o persoană orientată spre viitor este mult mai optimistă, motivată şi mai de succes. Totuşi, există unele aspecte, la care trebuie să atragem atenţie şi pe care trebuie să le observăm şi dirijăm permanent. Astfel, dacă persoana cade în extrema de a fi prea mult concentrată pe viitor sau doar pe viitor - ea îşi amână recompensele, plăcerile, sacrificându-şi deseori relaţiile personale,

${ }^{10}$ Vezi operele citate aparținând lui Charlotte STYLE, Larisa CuZnețov și Carol M. DWECK. 
aspiraţiile sau îşi subminează chiar sănătatea, ceea ce îi afectează bunăstarea psihofizică, morală, calitatea vieţii şi fericirea. Dacă, persoana este prea axată pe trecut, ei îi vine foarte greu să trăiască în prezent, speranţa la viaţă şi fericire sunt reduse, ea manifestă pesimism, sentimente de nostalgie, de părere de rău pentru tot ceea ce a trecut şi nu mai poate fi, etc.

Cel mai potrivit şi eficient aspect educativ şi de autoperfecţionare în acest sens, rezidă în faptul de a cultiva copiii, tinerii şi pe noi înşine în direcţia formării unei mentalităţi flexibile, conştiinţe temporale optime, care ar include toate perspectivele pozitive asupra timpului şi asupra vieţii, inclusiv ar presupune analiza obiectivă a tuturor experienţelor Pentru a înţelege ideea dată, vom prezenta câteva profiluri temporale de perspective optime, elaborate de $\mathrm{Ph}$. Zimbardo ${ }^{11}$, după cum urmează:

1. Perspectiva accentuat-pozitivă asupra trecutului, care ne ajută la acumularea experienţei de viaţă şi ne asigură rădăcini puternice, oferindu-ne o identitate autentică.

2. Perspectiva moderat-pozitivă asupra viitorului, care determină modul în care căutăm, trăim, soluţionăm provocările; stabilim, definim şi urmăm scopuri.

3. Perspectiva moderat-hedonistă şi eudaimonică asupra prezentului, care reflectă plăcerea oferită de ceea ce facem, şi cum facem şi ne oferă energie, plăcere, interes şi imbold pentru a ne mişca pe o spirală ascendentă a vieţii.

În contextul aspectelor analizate în procesul investigaţiilor noastre de durată privind educaţia pentru familie, ţinem să orientăm tinerii spre abordarea familiei ca pe un Proiect Existenţial foarte important, care ar avea la bază aceste trei tipuri de perspective, îmbinate armonios şi valorificate conştient în conformitate cu principiile morale şi strategiile psihologiei pozitive.

Întrucât am înţeles că dezvoltarea personală şi perspectivele vieţii sunt într-o strânsă legătură cu bunăstarea morală, spirituală şi psihofizică a persoanei, vom stabili ce putem face pentru ca acest proiect să fie realizabil, eficient, să asigure tinerei generaţii şi

${ }^{11}$ Charlotte STYLE, op. cit., p. 39-41. 
urmaşilor acesteia o viaţă calitativă, interesantă, inclusiv bunăstarea, prosperitatea şi optimismul, adică fericirea şi echilibrul psihologic.

În această ordine de idei, în primul rând, trebuie să ne dăm seama că fericirea noastră este afectată de numărul de opţiuni, specificul lor şi maniera în care le-am ales şi le abordăm. Analiza experienţei existenţiale a omului şi cercetările efectuate în domeniul psihologiei pozitive ${ }^{12}$ au demonstrat că oamenii aleg mai uşor şi sigur atunci când şi-au stabilit şi au clarificat priorităţile sale; au un număr mai mic de opţiuni şi când au un timp rezonabil pentru a le explora. Aşadar, persoanele care fac alegeri pot fi delimitate în două categorii: indivizii axaţi pe poziţiile maximaliste şi cei axaţi pe poziții satisfăcătoare.

Alegerea maximalistă nu întotdeauna corespunde realităţii, ea îi va cere persoanei prea mult timp pentru informare, analize, elaborare a unor planuri, strategii, scenarii pozitive, pe când alegerea satisfăcătoare este una mult mai adecvată şi funcţională. Aici luarea deciziilor reflectă nevoile şi opţiunile conştiente, raţionale, argumentate ale persoanei. Evident că uneori deciziile unui maximalist pot fi mai eficiente decât ale unui individ axat pe alegeri satisfăcătoare, însă viaţa arată că mai mulţumiţi şi fericiţi de la valorificarea acestora, totuşi rămân cei din urmă. În concluzie, noi optăm pentru alegeri îmbinate, adică să gândim şi să îmbinăm organic unele elemente din alegerile de tip maximalist cu unele alegeri de tip satisfăcător pentru a face alegerea cea mai potrivită/ optimă. În acest context, îndemnăm tinerii decişi să se căsătorească la discuţii comune şi la analize pe marginea problematicii centrate pe edificarea familiei, pe realizarea alegerilor şi proiectarea eficientă a tuturor aspectelor vieţii, perspectivelor, scopurilor, care presupun o coordonare, colaborare şi complementaritate conştientă şi coerentă de gen din partea ambilor parteneri în tot ceea ce se numeşte asiguraraea adaptabilităţii, coeziunii, armoniei, durabilităţii familiei şi a managementului familial calitativ, pentru a menţine, a administra şi a conduce cu succes familia.

12 B. SchwARtZ, A. WARD, J. Monterosso, et al., „Maximizing versus satisfying. Happiness is a matter of choice", in Journal of Personality and Social Psychology, 83/2002, p. 1181-1190; Charlotte STYLE, op. cit., p. 43-45. 
Evident că psihologia pozitivă studiază şi măsoară toate fenomenele care influenţează dezvoltarea personală a individului, calitatea vieţii omului, începând cu sănătatea şi longevitatea vieţii acestuia, edificarea şi menţinerea unei familii armonioase, unite, apte de adaptare socială şi economică; valorificarea iubirii, a ataşamentului uman şi, finalizând cu bucuria de la eficienţa personală a membrilor adulţi şi minori; de la posedarea simţului umorului, a capacităţii de autoevaluare, actualizare de sine, dezvoltare şi manifestare a rezilienţei (adică a competenţei de rezolvare a problemelor existenţiale, restabilirea persoanei în urma traumelor psihomorale).

Toate aspectele nominalizate reprezintă indicatori esenţiali ai bunăstării generale a omului, deci şi a fericirii. În acest context, ţinem să menţionăm o constatare foarte importantă a savanţilor din domeniul psihologiei pozitive, care ne atenţionează şi asupra faptului că o bună parte din fericirea omului este determinată genetic ${ }^{13}$. Adică să înţelegem că nu numai mediul/ cultura, educaţia şi autoperfecţionarea sunt importante, dar contează şi factorul biologic.

Plecând de la cele relatate anterior, vom urmări care este traseul şi care sunt condiţiile întemeierii şi menţinerii bunăstării generale a familiei, a tuturor membrilor ei, adulţi şi minori. Considerăm că fiecare persoană, care doreşte să-şi creeze o familie, este, pur şi simplu, obligată să fie ea fericită şi să contribuie la edificarea fericirii celor apropiaţi. Această axiomă poate fi abordată ca scop, ca perspectivă vitală, ca prioritate valorică şi ca Proiect Existenţial Uman.

Este cunoscut faptul că modelul familial şi cel parental din familia de origine a persoanei au un rol decisiv în procesul de iniţiere şi constituire a propriei familii. Comunicarea şi relaţionarea eficientă, exemplul pozitiv de convieţuire al propriilor părinţi, calitatea managementului familial (luarea şi realizarea deciziilor), al creşterii şi educaţiei copiilor - sunt cele mai importante repere axiologice şi praxiologice, de la care învaţă copiii noştri şi pe care le urmează în viaţa sa adultă. Iată de ce fiecare

${ }^{13}$ Charlotte STYLE, op. cit., p. 9. 
familist/ adult este dator să depună efort pentru a duce o viaţă demnă, sănătoasă din punct de vedere fizic şi moral, pentru a contribui la crearea şi fortificarea condiţiei biologice pozitive şi viguroase, importantă pentru viitorii descendenţi, dar şi pentru sine, pentru a fi el fericit şi a-i face fericiţi pe ceilalţi din jurul său, inclusiv pe urmaşi, pe cei din perspectiva lui de viitor. În esenţă, aceasta este axa doctrinală a lucrărilor noastre, dedicate sociopsihopedagogiei şi filosofiei practice a familiei şi desigur că acest postulat important ar fi o condiţie centrală, chiar primordială, în elaborarea, monitorizarea şi explorarea celui mai important Proiect al vieţii omeneşti - Familia fericită.

$\mathrm{O}$ a doua condiţie se poate rezuma la o pregătire teoretică bună în ceea ce priveşte cunoaşterea particularităţilor psihologice ale persoanei, a etapelor şi crizelor de vârstă, a trăsăturilor de personalitate; a posibilităţilor şi modalităţilor dezvoltării eficienţei intelectuale, morale, tehnologice, psihologice, spirituale, estetice etc.

$\mathrm{O}$ a treia condiţie se configurează în jurul necesităţii partenerilor de a se cunoaşte bine pe sine şi pe celălalt, pentru a fi în stare să dezvolte punctele pozitive/ forte ale personalităţii, anihilându-le sau chiar lichidându-le pe cele negative, slabe.

Următoarea condiţie, a patra, se poate formula în felul următor: centrarea pe un mod de viaţă sănătos, responsabil şi demn din punct de vedere moral, fizic şi spiritual.

Încă o condiţie importantă o considerăm respectarea drepturilor omului, a copilului în îmbinare cu onorarea obligaţiunilor, orientate spre o colaborare eficientă în realizarea funcţiilor managementului familial şi a educaţiei copiilor.

$\mathrm{O}$ altă condiţie deosebit de importantă pentru realizarea calitativă a acestui proiect grandios uman este implicarea conştientă, responsabilă, creativă şi activă a ambilor parteneri conjugali în elaborarea, fundamentarea, valorificarea şi monitorizarea acţiunilor, perspectivelor şi strategiilor de obţinere a scopului suprem: fericirea şi împlinirea, armonia relaţiilor şi bunăstarea generală a fiecărui membru familial, a întregului sistem familial.

În concluzie, dezvoltarea personală în corelare cu o perspectivă moderat - pozitivă, axată pe prezent şi pe viitor o putem 
Perspectivele vieții persoanei: dezvoltarea personală și proiectul existențial de edificare a familiei fericite

defini ca factor şi/ sau condiţie pentru edificarea şi menţinerea unei familii armonioase, durabile şi fericite (acest lucru a fost evidenţiat de întregul eşantion care a participat la investigaţie).

$\cos 80$

\section{Bibliografie}

1. BonIwell, Ilona, Positive Psychology in a Nutshell, Londra, PWBC, 2006.

2. Cuzneţov, Larisa, Familia ca Proiect Existenţial. Management familial, Chişinău, Primex Com-SR1, 2019.

3. IDEM, Filosofia practică a familiei, Chişinău, CEP USM, 2013.

4. IDEM, Tratat de educaţie pentru familie. Pedagogia familiei, Chişinău, CEP USM, 2008.

5. DwECK, Carol, M. The new psychology of succes, NewYork, Ballantne Books, 2006.

6. SCHWARTZ, B., Ward, A., Monterosso, J. et al., „Maximizing versus satisfying. Happiness is a matter of choice", în Journal of Personality and Social Psychology, 83/2002, p. 1178-1197.

7. STYLe, Charlotte, Psihologia pozitivă. Ce ne menţine fericiţi, optimişti şi motivaţi, Bucureşti, Edit. All, 2015. 